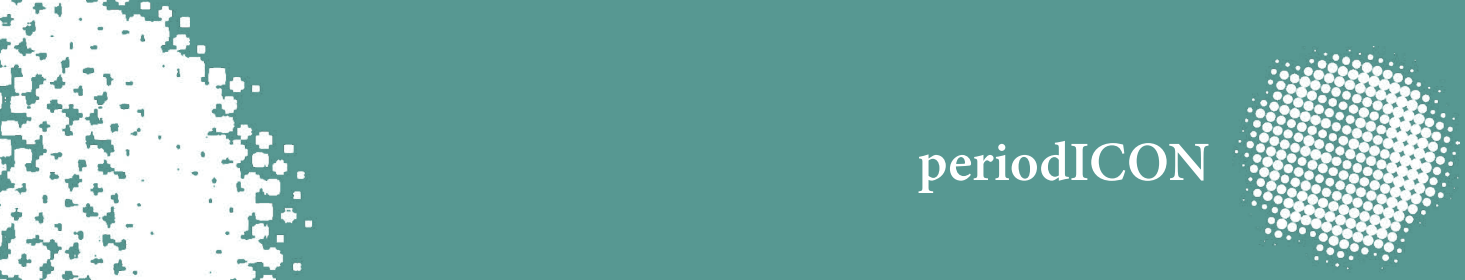

Studien zur visuellen Kultur des Journals Studies in the Visual Culture of Journals

\title{
Driving Wild Cattle in Illustrated Magazines from Britain to France, and from France to Germany
}

\section{Migrating Illustrations as a Means of National Self-Assurance}

\section{Andreas Beck}

RUHR UNIVERSITY BOCHUM

\section{periodICON}

Studien zur visuellen Kultur des Journals | Studies in the Visual Culture of Journals

herausgegeben von | edited by

DFG-Research Unit 2288 »ournal Literature»

ISSN 2628-8354

Vol. 1 (2021) | No. 1

DOI: https://doi.org/10.46586/PerIc.2021.1.1-20

(cc) BY-NC-ND Except where otherwise noted, this work is licensed under a Creative Commons

This journal is hosted by Ruhr-University Bochum https://ojs.ub.rub.de/index.php/PerIc/

\section{GASIN PITTORESQUE.}

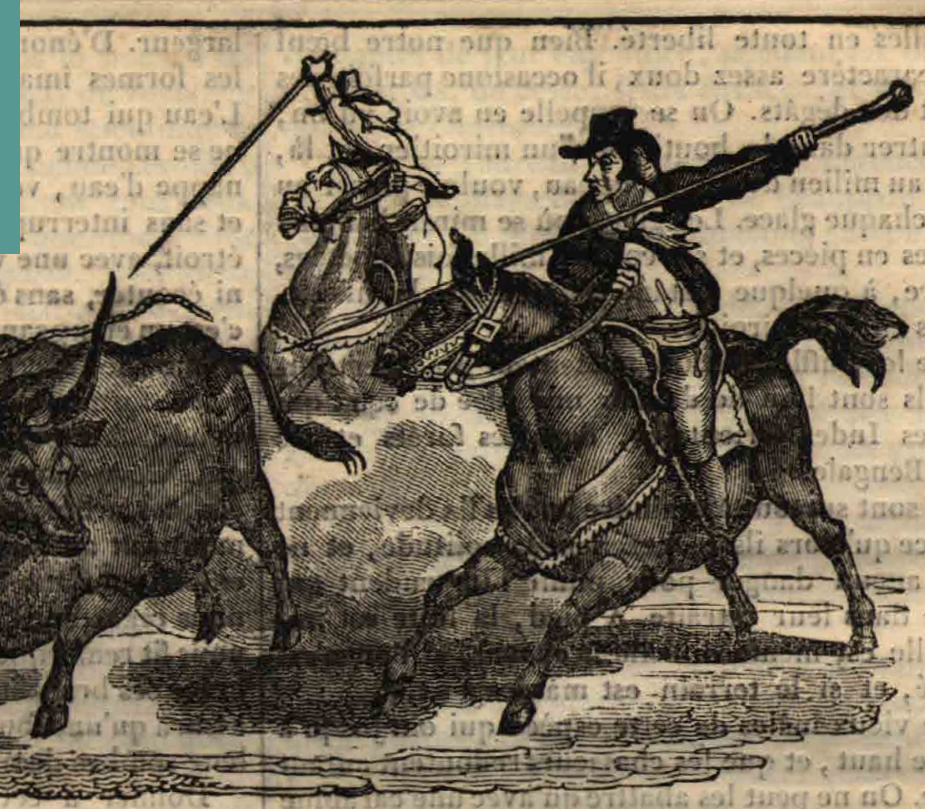

BOEUFS SAUVAGES DANS LA MAREMME

s ouvrages de géographie, on désigne sous le leur course, tout cet aspect sauvage contraste Maremme cette contrée du grand-duché de qui borde la mer Méditerranée; mais en réait aussi comprendre sous ce nom la campagne car c'est partont la mème nature.

t la moitié de lannée, cette váste étendue de sé đéveloppe sur unc longueur de cent fieues, e, frappe de ce cruet flíau qu'on appelle mal yoyageurs qui Tount trấếrsée à cette époque 1 gư mie plame abandonncé, ils ont pris pour s les grandes teires qư on laisse reposer penieurs années, et si parfois, de loin en loin pâtres leur ont apparu, cetait pour leur offrir ndes empreintes de Pinfluenee funeste du

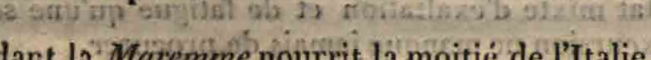
riche et produetif. Pendant que les fièvres sont s, on se hâte de dérober au sol-les richesses le. "On y voit alors, dit M. Didier, voyageur de déciire cette contrẻe pittoresque, cent attelées à la fois de dẹux, trois, jusqu'à qua5 de' boeufs sauvages, labourant de front un : deux i trois Tieties. Telles semailles, telles : déchiréés par de si puissans moyens, les turniennes ne sont ni rebelles ni ingrates, et fécond ne s'ouvre pas en vain. Quand vient Ha récolte, le fleuve dés moissonneurs descenpontagmes les inonde, et la solitude est tout- rement avec l'ordre et la régülarité qui rèğne lieu des troupeaux; la se manifeste à un $h$ l'empire de $q^{2}$ intelligence sur la force brutale encore M. Didier : "Ce quil y a de plus $g$ avec la moisson, dans lagriculture des $M$ $c^{\prime}$ est le gôivernement des trompeaux. Päs $p$ moissonneur le pẩtre n'est indiggèné; deseẹn lui des montagnes dans la saison des neiges, il au printemps, et ses froupealux aveć lui. Roi le pátre se-promène en roi dans son empire. et la lance au poing, il mesure d'un oeil arden! sans bornes, et rien n'ćchappe à sa vigilance au taureau rebelle, à l'étalon révolté qui jette ordre au sein du troupeau! le fer aigu se tei sang enflammé; ils rentrent confus dans le ri brute indocile et vaincue reconuait dans the maitre : elle subit son joug en silence."

La gravure qui est en tête de cet article i deux buffles qui couraient à la maraude, pasteurs ramènent; celle qui suit montré qua animatix attachés sous un même joug, et con ville. Peut-être devrait-orien France adopter un

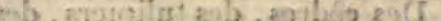

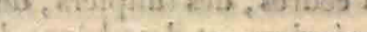
2)

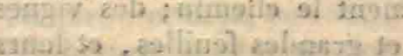

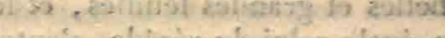




\title{
Driving Wild Cattle in Illustrated Magazines from Britain to France, and from France to Germany
}

\section{Migrating Illustrations as a Means of National Self-Assurance}

\section{Andreas Beck}

RUHR UNIVERSITY BOCHUM

\begin{abstract}
The following case study on English, French, and German penny magazines from the 1830s aims to make visible a mostly overlooked way of producing and diffusing knowledge-not least ethnographic knowledge-in early illustrated magazines. By investigating an example of trading stereotyped wood engravings between England, France, and Germany, the present paper retraces the development of a periodical-specific international verbal-visual syntax which was triggered by the emergence of illustration. It retraces how magazine makers learned within a few months to give meaning to illustrated periodicals' layout, to the arrangement of thematically heterogeneous articles' letterpress and images on a double-page spread-and how they used the semanticized mise-en-page of their magazines' openings to express international connections and tensions. Thus, the page design of illustrated periodicals turns out to be a means of an implicit ethnography, an instrument to render the profile of the own nation, $\varepsilon^{\prime} \theta v o \varsigma$, readable and visible by $\gamma \rho \alpha \varphi \eta$, by printed writing and wood-engraved drawings.
\end{abstract}

\section{Keywords}

illustration history, wood engraving, image/text relationship, page design, layout strategies, international stereotype trading, penny magazines 
$\mathrm{T}$ he present paper sets out to demonstrate that, immediately upon its emergence in the early 1830s, the new media format of the illustrated magazine was used to produce ethnographic knowledge. Certainly, at first sight it might seem not necessary to prove this: Leafing through early illustrated penny magazines from England, France, and Germany, reader-viewers are confronted with accounts, for example, on Bushmen and Hottentots in Southern Africa, Neapolitan maccaroni-eaters, ${ }^{2}$ the Charrua in Brazil, ${ }^{3}$ or Hindu festivals. ${ }^{4}$ The considerable frequency of ethnographic subjects in these periodicals is obvious, and consequently, scholars have stated their relevance. ${ }^{5}$ However, I will not focus on such explicitly ethnographic statements but on a specific type of implicit ones, namely on ethnographic connotations of layout strategies in these early illustrated magazines, i.e. on the placing of images and letterpress together on a page (or rather on a double-page spread) as a comment on the relationship between certain nations. In other words: my task is to show that in its visibility, the illustrated text of these periodicals, as a print combining typeset text and wood engraving, can (and perhaps even should) be read-viewed as an act of drawing a nation's profile.

As such, the following case study has a methodological aim when investigating a characteristic example of the connections between the London Penny Magazine, the Paris Magasin Pittoresque, and the Leipzig Pfennig-Magazin. Asking how (print-)medial frames shape knowledge-here: inter-national ethnographic knowledge-, we have to consider basic paratextual ${ }^{6}$ features in the respective documents; amongst others, as I want to argue, we have to examine closely the extent to which the visual appearance of the printed page as a designed surface, usually ignored by scholarship, ${ }^{7}$ contributes to the text's message. Sometimes, the visual design of the page or opening (by which I refer to the double-page spread, also further in the course of the paper) may even constitute this message, and this is quite commonly the case in the first years of the first illustrated magazines. Due to the international situation in terms of producing wood-engraved illustrations, a well-planned layout was, especially in Germany, a privileged mode of verbal-visual communication-not least when producing and spreading a certain kind of ethnographic knowledge.

\section{Rule Britannia?}

The Emergence of Pictorial >Illustration in the $1830 \mathrm{~s}$

An »illustration, « as the Oxford Advanced Learner's Dictionary puts it, is "a drawing or picture in a book, magazine, for decoration or to explain something. « ${ }^{8}$ This meaning of the term is a rather recent one, arising in the second third of the nineteenth century. ${ }^{9}$ At this time, it became technically possible to publish plenty of images, printed together with letterpress, in high circulation weekly periodicals. ${ }^{10}$ The first of these periodicals, the
London Penny Magazine, was launched in 1832, and by 1836 , the total circulation of this media type in Europe and America was already in the millions. ${ }^{11}$ Almost overnight, reader-viewers were confronted with a flood of printed texts containing many wood engravings - so that, in consequence, the meaning of sillustration< shifted from >verbal explanation ${ }^{12}$ to requipment of printed texts with images of solid quality in a quantitatively new way: new in terms of both the high number of pictures in printed texts and the high circulation of these image-heavy prints.$^{13}$

With the emergence of sillustration as we know it today, triggered by xylographically equipped magazines, the early nineteenth century saw a stunning media revolution, and Britain self-confidently exhibited her merits as the first, and (until the mid-1830s) leading producer of illustrated texts. In 1833, the Penny Magazine proudly (and maliciously) states that »the art of wood-cutting is imperfectly understood in France and Germany; «" $"$ however excellent France and Germany may be in other branches of engraving, they have at present scarcely any woodcutters amongst them. « $^{15}$ Regarding Germany, this is, alas, quite right; just compare John Jackson's engraving - the Penny Magazine celebrates him as »one of the best wood-cutters of our day « ${ }^{16}$ - of Strasbourg Cathedral in the Penny Magazine (fig. 1a) ${ }^{17}$ with the Pfennig-Magazin's deplorable depiction of Ulm Minster (fig. 1b) ${ }^{18}$ which clumsily imitates the pictorial strategies of the English wood engraver. ${ }^{19}$ There is, indeed, as the Penny Magazine won- 


\section{THE PENNY MAGAZINE}

Society for the Diffusion of Useful Knowledge.

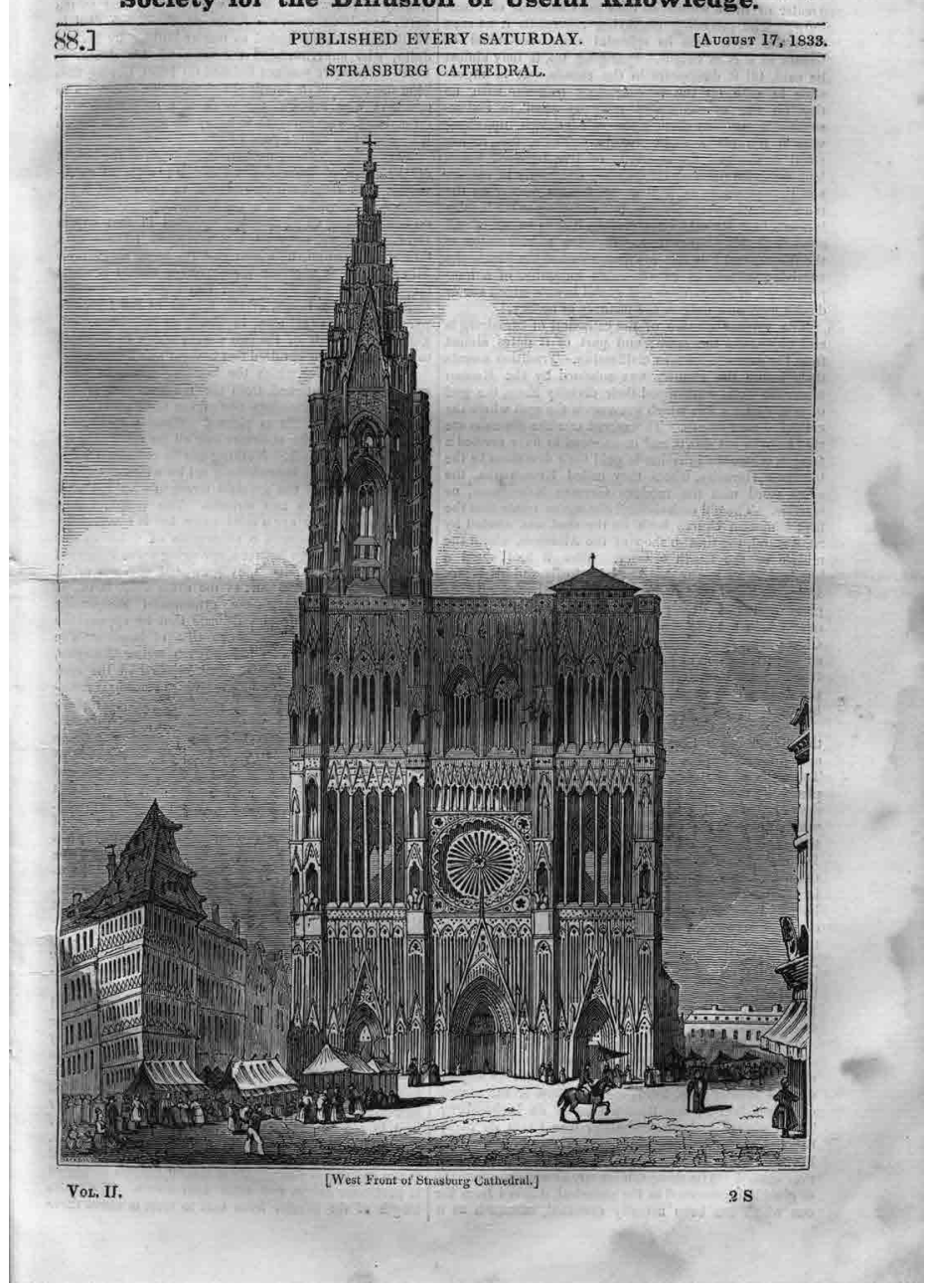

Strasbourg Cathedral. Wood engraving, drawing and engraving by John Jackson; signed »JACKSON « in the lower left corner. Penny Magazine 2, no. 88 (August 17, 1833): 313; type area ca. $25.4 \mathrm{~cm} \times 15.3 \mathrm{~cm}$. Early copy, formerly in the library of the English Book Society Hanover (Germany); author's collection.

\section{Das $\mathfrak{p f e n n i g - ~} \mathfrak{A l a g a z i n}$}

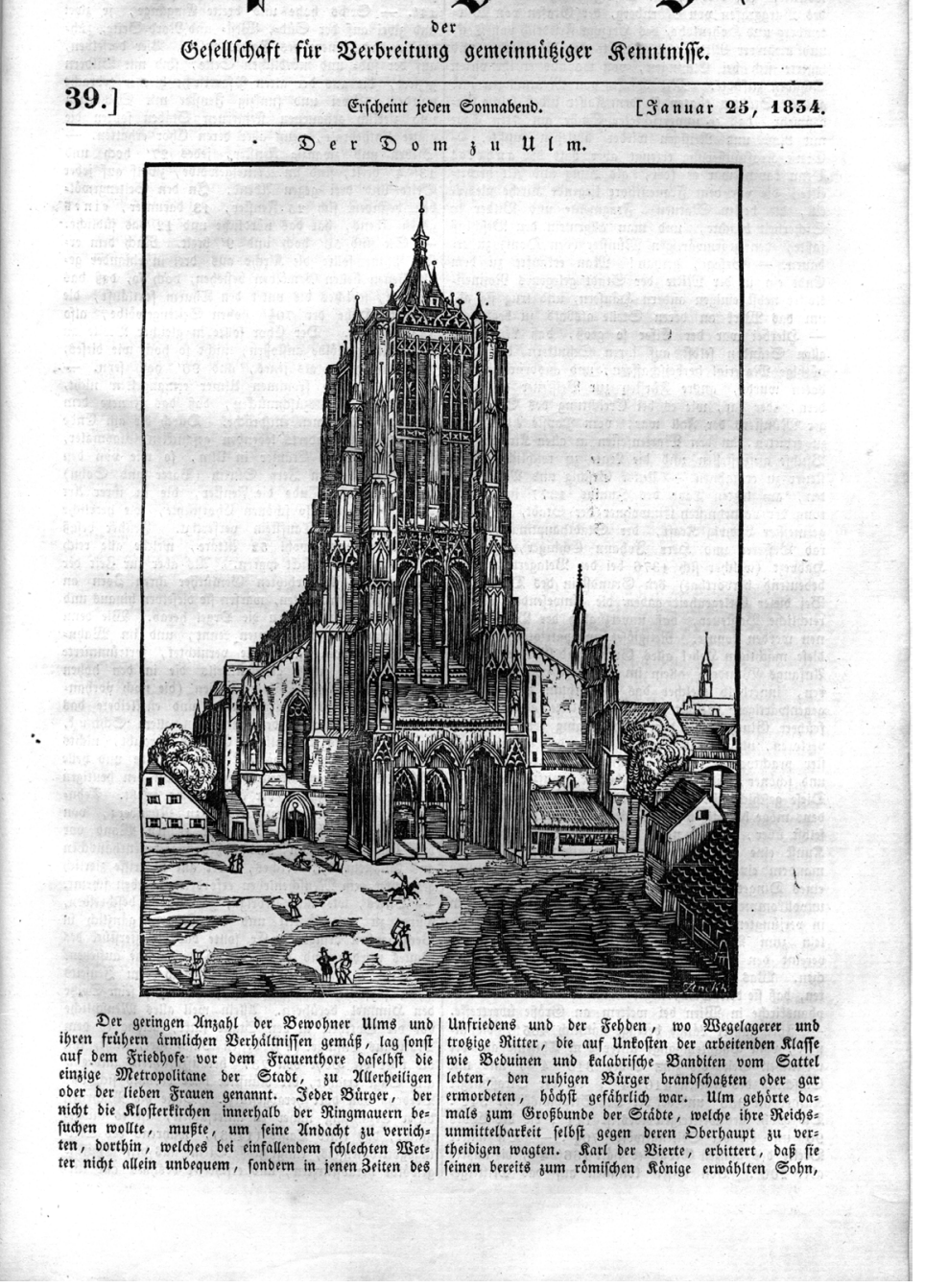

Ulm Minster. Wood engraving, signed »Finckh« in the lower right corner. Pfennig Magazin 1, no. 39 (January 25, 1834): 305; type area ca. $24.9 \mathrm{~cm} \times 15.2 \mathrm{~cm}$. Early copy, formerly in the Stadt-Bibliothek Breslau/Königliche und UniversitätsBibliothek Breslau (Wrocław); Theodor Springmann-Stiftung, Heidelberg. 
ders, "a singular contrast to the state of things in Germany soon after the invention of printing, «a gap between the present and the epoch of »Albert Durer, [...] Wohlgemuth [...], and [...] Holbein. $^{20}$ By these artists »wood-engraving was carried to a perfection which it subsequently lost till its revival in our own country, by Bewick. ${ }^{21}$

But glorious Britain provides a helping hand: "We sell, therefore, « the makers of the Penny Magazine declare, "to France and Germany casts of our wood-cuts, at a tenth of what it would cost them to have them re-engraved. These countries are thus enabled to produce their $>$ Magasin Pittoresque,

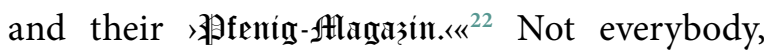
however, appreciates this patronizing generosity; the Sonntags-Magazin (although itself a mere imitation of a French illustrated weekly, of the Musée des Familles) criticizes the Pfennig-Magazin as sa rather dull copy of English journals, ${ }^{23}$ as a in some sense parodistic imitation of foreign originals ${ }^{24}$-and the makers of the Pfennig-Magazin do not reject these reproaches but promise that they will eagerly strive to give a more and more national character to this periodical. ${ }^{25}$ Obviously, the emergence of iillustration<, the abundant use of wood engravings in magazines in the 1830s, is a matter of national (or inter-national) concern, a matter of national pride for some and humiliation for others; it opens a course where Germany (as well as France) has to keep pace with other countries, especially with Britain. And so one might ask how it was possible, in the 1830s, to run an illustrated German »National-Magazin $\aleph^{26}$ if this snational magazine- - as well the Sonntags- and the Pfennig-Magazin-printed most of its illustrations from type metal copies of foreign wood engravings, from stereotypes imported from abroad?

Paradoxically, the almost total dependence of German illustrated magazines on foreign materials opened the way to a sort of nationak page design. Transnational stereotype trading opened a field of experimentation: allowing refined rearrangements of illustrated texts borrowed from abroad, migrating stereotypes pushed forward the development of a new image/letterpress syntax in illustrated texts; they pushed forward a development which was not at least driven by attempts of the borrowers of stereotypes to surpass the layout solutions of the providers of these casts. Thus, by stereotype trading the double-page spread of illustrated periodicals became a fundamental unit of innovative verbal-visual design and communication that also served national self-assurance. When, due to migrating stereotypes, letterpress and wood engravings begin to interact in openings of illustrated magazines across the borders of single pages and articles, these interactions should be read-viewed not least as part of an Anglo-French-German competition in which German magazine makers in particular skilfully turned, in a way, foreign leaden stereotypes into snational stereotypes‘.
The Periodical's Fear of

\section{Its Textual Dynamics}

\section{Layout-Tamed Wild Cattle}

in the Penny Magazine

To make this point of view persuasive, I would like to retrace the migration of wild Italian cattle, by means of stereotypes, from London to Leipzig via Paris in early illustrated magazines. In August 1832, the London Penny Magazine featured an article on the miserable working conditions in the Italian region of Maremma (fig. 2). ${ }^{27}$ This account, with its two wood engravings, occupies almost the entire double-page spread-that begins to acquire compositional relevance, although at first sight the visual appearance of the illustrated text seems to be due to a benchmark independent of visual design strategies. The position of the xylographic images is defined by the article's extent, they mark its beginning and ending, they frame it and thus present it as a whole. This logocentric operation runs counter to the illustrations' iconic dimension as the depiction of violent dynamics-the wood engravings show involuntary movement of the wild cattle-is contrary to the static framing function of the images. This tension seems to be well calculated: at the top of the left-hand page, two cows are driven leftwards, towards the page's margin where they cannot continue their stampede. Thus, the catchers drive the cows to the left column of letterpress, to the beginning of the article which >catches the animals by visual and verbal depiction. Accordingly, the ox in the foreground 
turns its head rightwards, against the direction of escape: at the beginning of the account, corresponding to our direction of reading-viewing the illustrated text, it looks at its subjugated colleagues at the article's ending, which are driven, as it were, against the dividing line between the typeset text's columns. Thus, the dynamics of the iconically depicted objects are inhibited by letterpress on the physical surface of the opening: While the account tells that und shows how wild cattle is driven into towns to be sold there, ${ }^{28}$ the Penny Magazine does something similar through its layout, namely verbal-visually subduing the article's untamed subject to be sold in the city of London (and elsewhere).

And yet, this appealing verbal-visual composition is rather cautious in terms of the young illustrated magazine's potential: not only the dynamic in the movement of the wild oxen are curbed here, but also the specific dynamics of the periodical. Framed by its illustrations, the Maremma article is anxiously presented as self-contained, as a text secured against its thematically heterogeneous surroundings, and as a text which does not, with the inward-looking motion of its wood engravings, unfold verbal-visual dynamics which might intrude into the territory of neighboring texts. This quite static textual constellation becomes more lively when the Magasin Pittoresque imports the Italian cattle from England in March 1833 by means of stereotypes. On this occasion, the Paris counterpart of the Penny Magazine unfolds the illustrated periodical's opening as a design unit

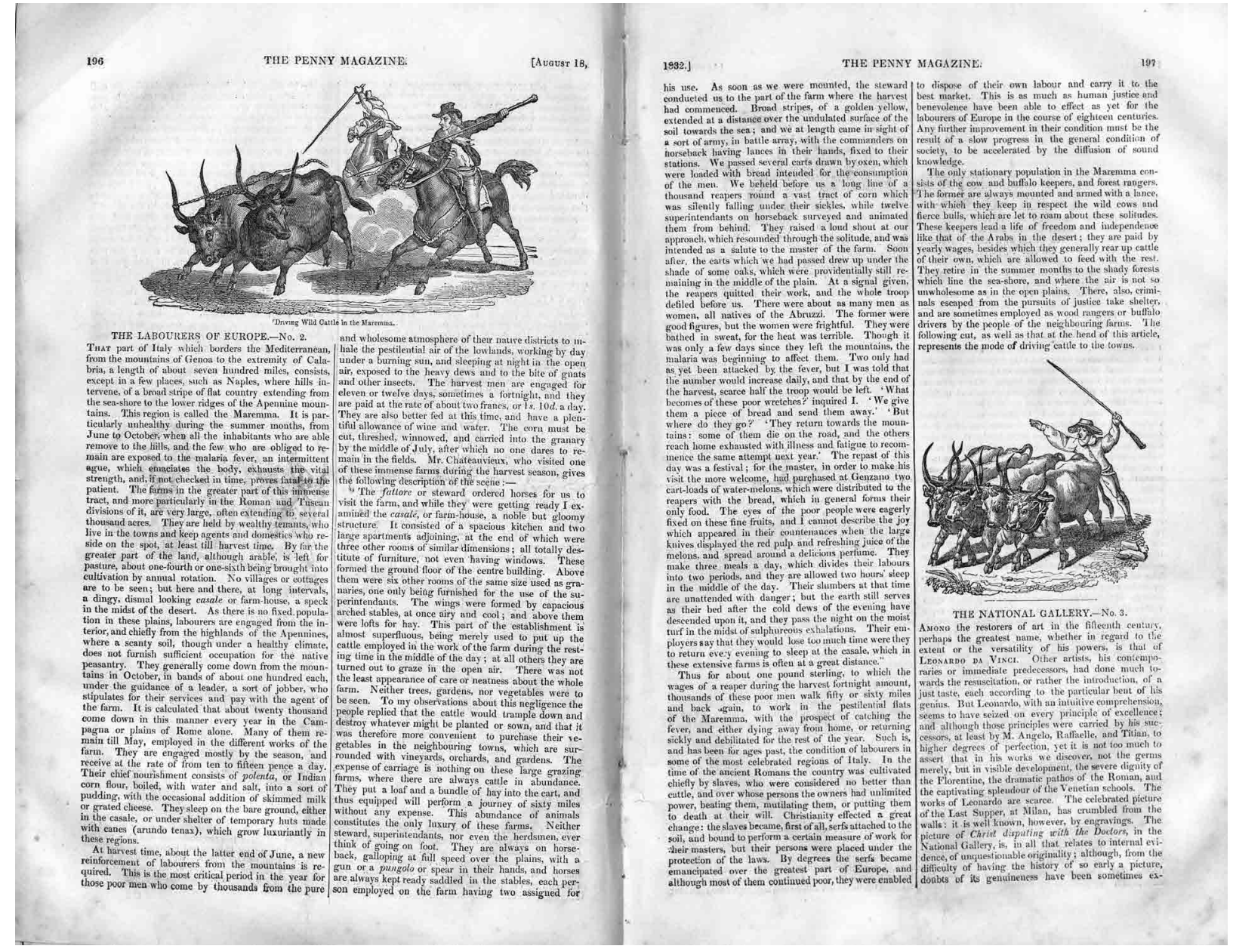

fig. 2 "The Labourers of Europe.-No. 2." Penny Magazine 1, no. 24, (August 18, 1832): 196-97;

type area ca. $25.4 \mathrm{~cm} \times 15.3 \mathrm{~cm}$. Wood engravings without signature. Early copy, formerly in the library of the English Book Society Hanover (Germany); author's collection. 
that displays interactions of different texts in the miscellaneously organized magazine.

Unfolding the Animal Vigor of the Periodical's Text on the Periodical's Unfolded Opening

The Mise-en-Page of the Wild Cattle in the Magasin Pittoresque

In the Magasin Pittoresque, the considerably abridged Maremma account does not take up almost the entire opening, but just a little more than the right-hand page, where the two wood engravings from the Penny Magazine are placed one below the other (fig. 3). ${ }^{29}$ This concentration of images opens a space of effect for the physical commotion depicted by the two illustrations. Unlike in the Penny Magazine, the movement of the reader-viewer's eye from the left to the right, from the article's beginning to its ending, does not dominate the act of reception. The Magasin Pittoresque does not aim at a reading-viewing which runs against the dynamics of the engravings and consequently progresses from the bigger image with its galloping cattle and horsemen to the smaller one and the moderate pace of the subjugated oxen driven by a man walking. On the contrary, in the French magazine the two illustrations at the right margin accummulate to create a leftwards-oriented aggressive pressure against the reading direction, and successfully so, for their movement, pointing beyond the limits of the Maremma ac-
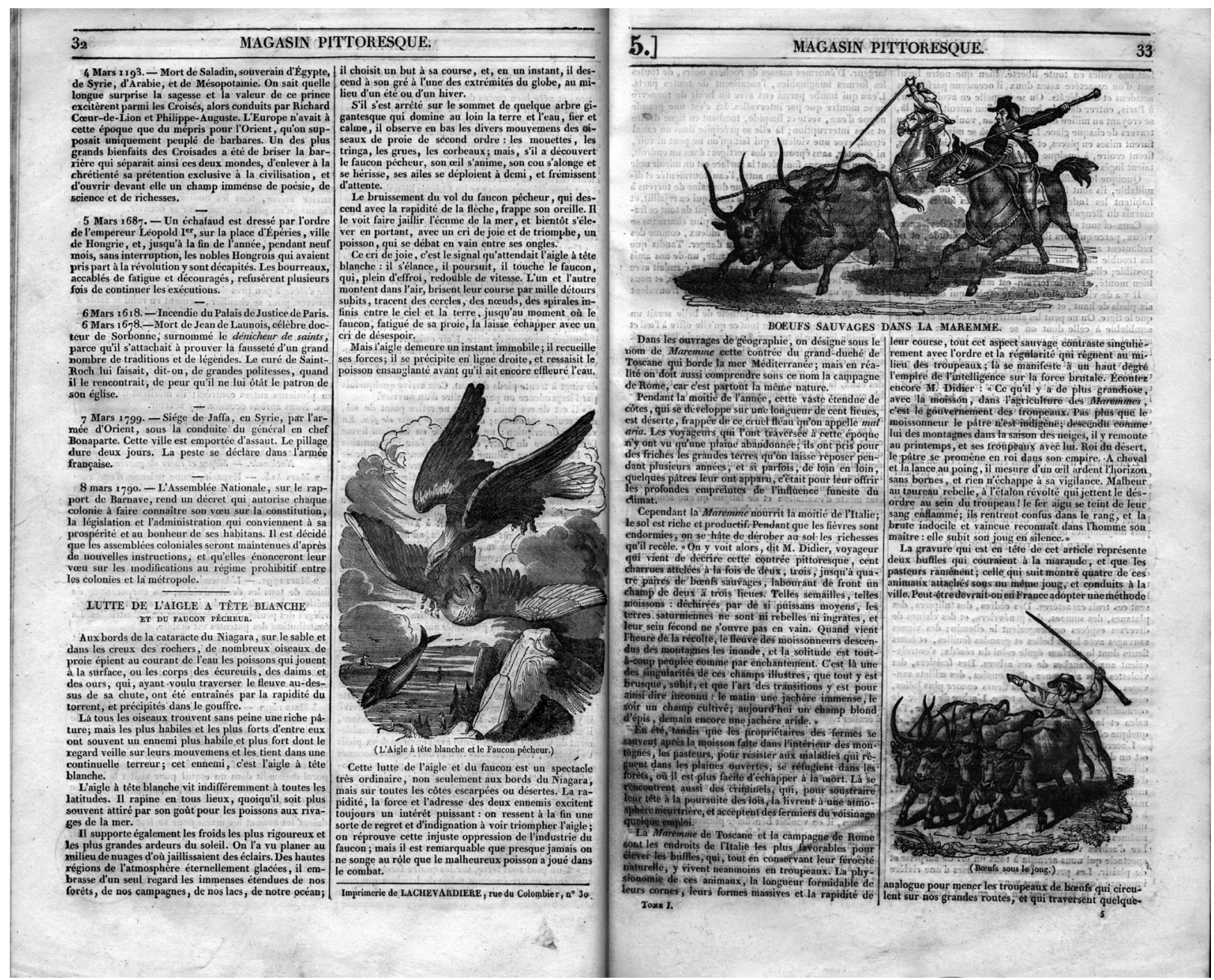

fig. 3 »Lutte de l'aigle à tête blanche et du faucon pêcheur.« (left-hand page, wood engraving without signature), and »Bœuf sauvage dans la Maremme.« (right-hand page) Magasin Pittoresque 1, no. 4 and 5 ([March 2 and 9, 1833]): 32-33; type area ca. $25.5 \mathrm{~cm} \times 15.3 \mathrm{~cm}$. Early copy, stamped issues (tax stamps ibid., 31 and 40); author's collection, no digitized copy available. 


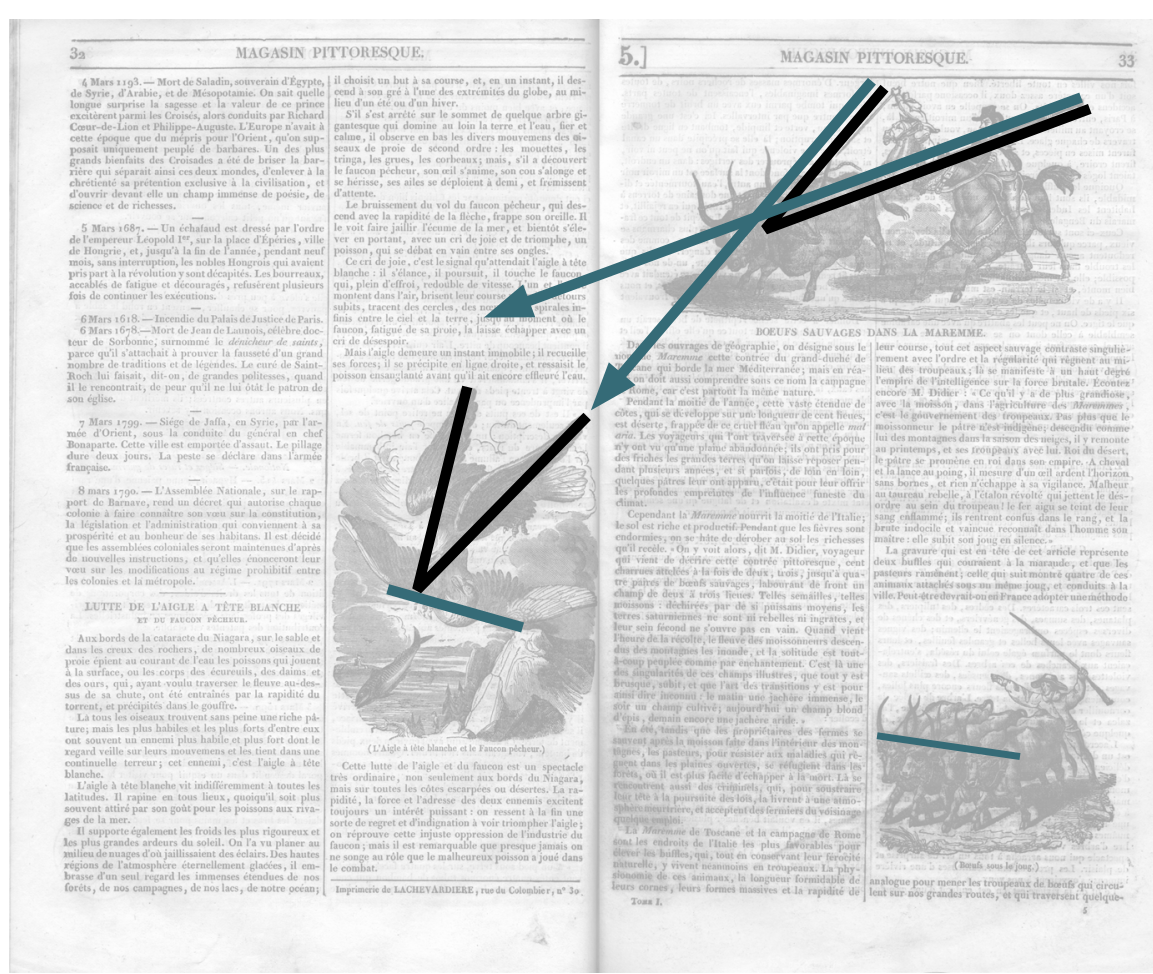

fig. 3a Lines of interaction between the driven cattle and the

fighting raptors in the Magasin Pittoresque.

count, is taken up on the left-hand page by a third illustration in another article (also borrowed from the Penny Magazine): ${ }^{30}$ the xylographic depiction of the white-headed eagle attacking the fish hawk renews the dynamics of the wild cattle by a similar aggressive impulse (fig. 3a).

The impact direction of the front horseman's lance, together with the escape direction of the wild cattle top right, leads to the attacking white-headed eagle, which is related to cattle and catchers furthermore in terms of image composition: the oxen correspond to the head and the trunk of the eagle, while the lances form a counterpart to its wings. This link between the illustrations is complemented by a second one: the line marked by the cattle's yoke in the engraving bottom right corresponds to the tilt of the succumbing fish

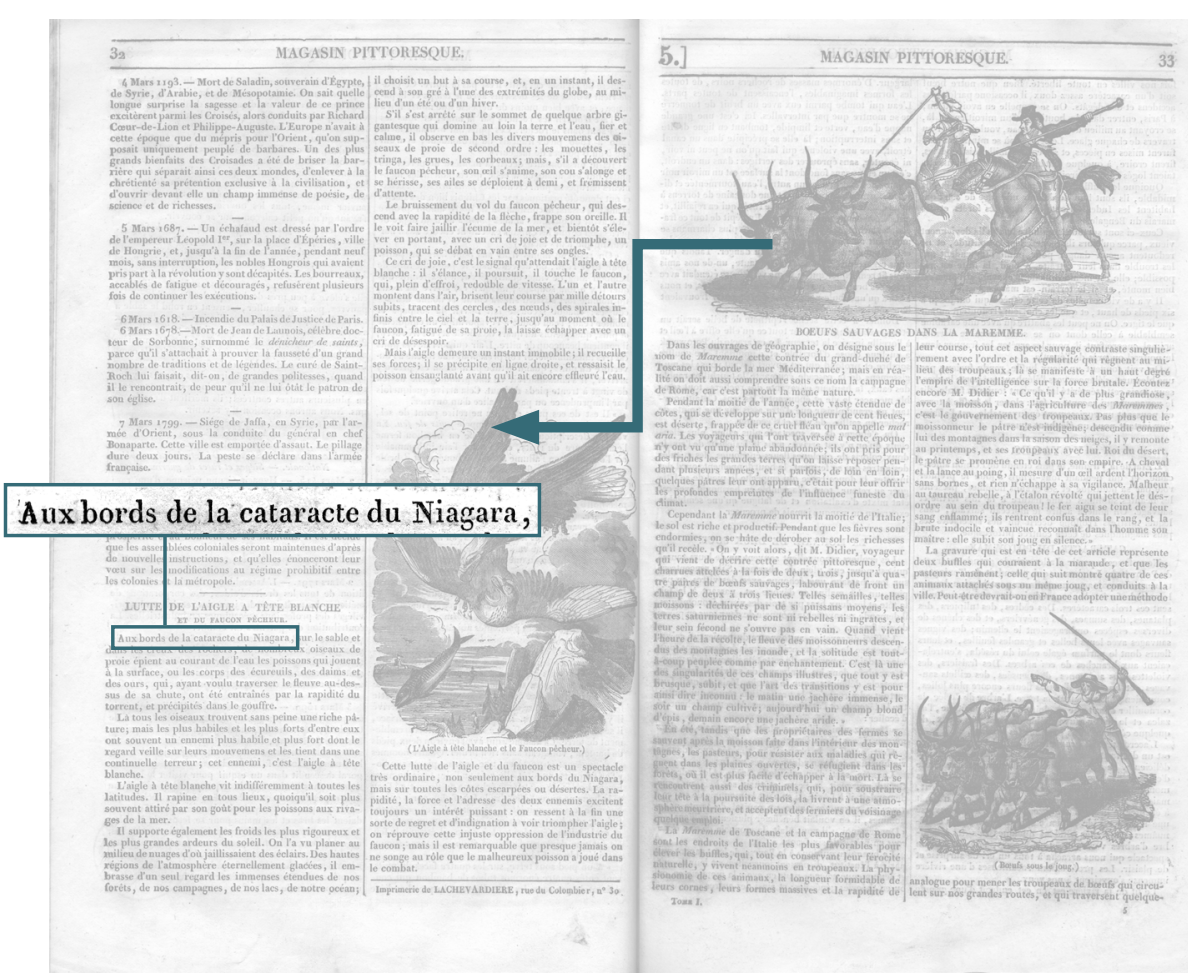

fig. 3b Reenactment of the Niagara waterfall in the Magasin Pittoresque by arranging together heterogeneous illustrated articles on the magazine's opening.

hawk. The lines of twofold aggression, running from the page's right margin leftwards towards each other, thus meet on the opposite page, in the pictorial composition of the raptors' fight.

By means of this cooperation of illustrations across typematter and across the borders of articles and pages, the Magasin Pittoresque allows, unlike the Penny Magazine previously, to grasp the illustrated periodical's opening, which was modeled by stereotype trading, as a design unit typical of this media format. Stereotype trading allowed French magazine makers a deliberate rearrangement of English wood engravings and thus the creation of a convincing opening layout, superior to their British predecessors. Superior, because when the Magasin Pittoresque arranges together images and letterpress 
on the opening's surface, it successfully deals with the illustrated magazine's thematically heterogeneous and miscellaneous organization, which seems to have been a problem for the makers of the Penny Magazine. In other words: the Magasin Pittoresque here uses the double-page spread as a unit of a new verbal-visual syntax, characteristic for the new genre of the illustrated magazine.

Let us just compare once again the British and the French magazine. Framing the Maremma account by illustrations, the Penny Magazine makes the article's letterpress visible as an extensive plain of typeset text that impedes the dynamics of the wood engraved depictions; the typeset columns in front of the illustration on the right-hand side thwart the cattle, the oxen are driven against the dividing line. To achieve this semantization of the optical quality of the typeset text-it expresses violence against the cattle less by its explicit meaning than implicitly by its visibility-it is not necessary to combine thematically heterogeneous articles, but doing so proves to be more effective. The Magasin Pittoresque also models typeset text in its visibility as an obstacle that heightens the intensity of the xylographic depictions-but as an obstacle overcome by the force of illustrations belonging to diverse articles (fig. 3b). Across the gutter, through a gap between the blocks of typematter that is, at the same time, a gap between different articles, the dynamics of the upper wood engraving tilted to the downside make a breakthrough-corresponding thus to the scataract of

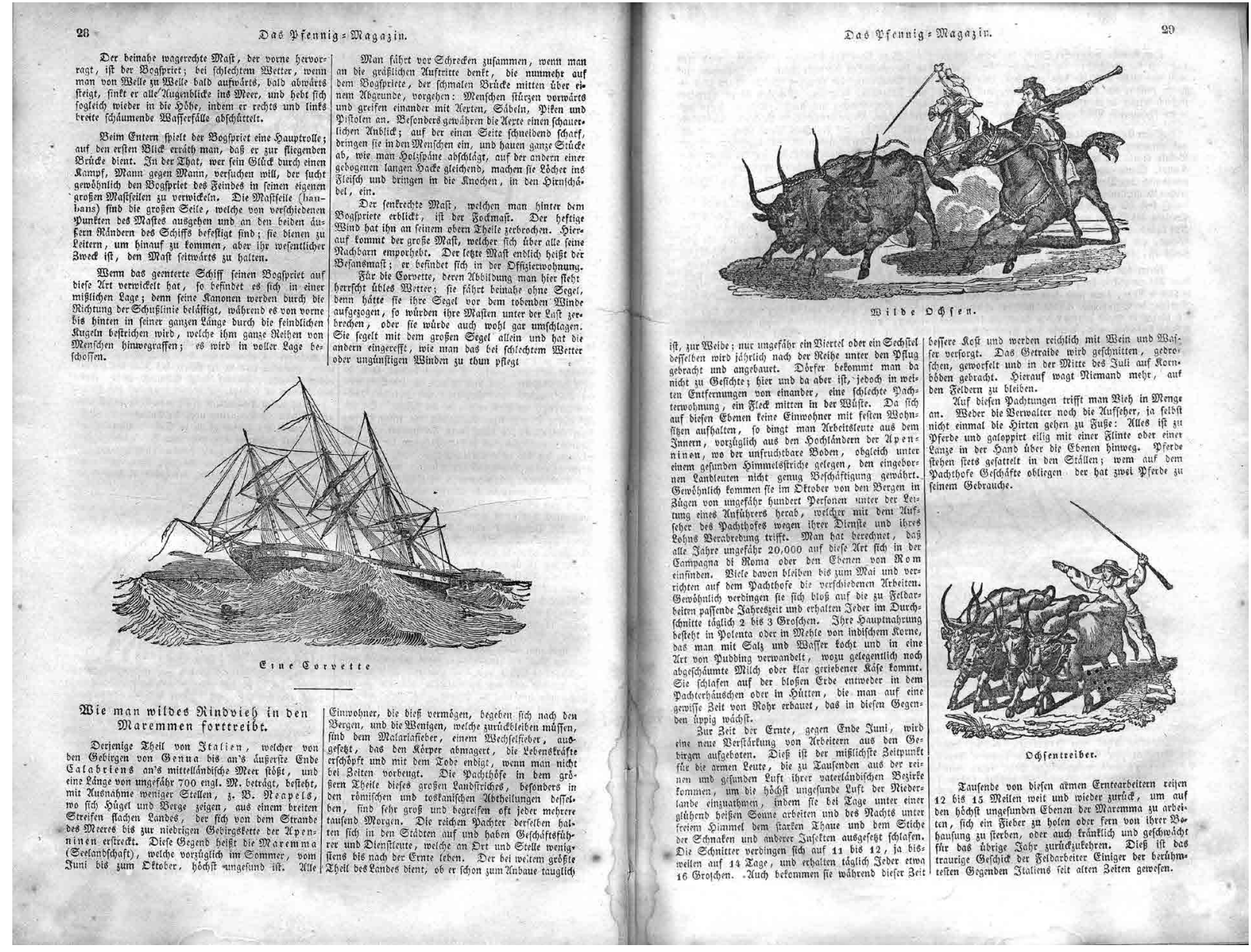

fig. 4 »Eine Corvette.« (left-hand page, the drawer's and the engraver's signatures at the bottom of the wood engraving have been removed, cf. fig. 6), and »Wie man wildes Rindvieh in den Maremmen forttreibt. (right-hand page) PfennigMagazin 1, no. 4 (May 25, 1833): 28-29; type area ca. $25.0 \mathrm{~cm} \times 15.1 \mathrm{~cm}$. Early copy, formerly in the Stadt-Bibliothek Breslau/Königliche und Universitäts-Bibliothek Breslau (Wrocław); Theodor Springmann-Stiftung, Heidelberg. 


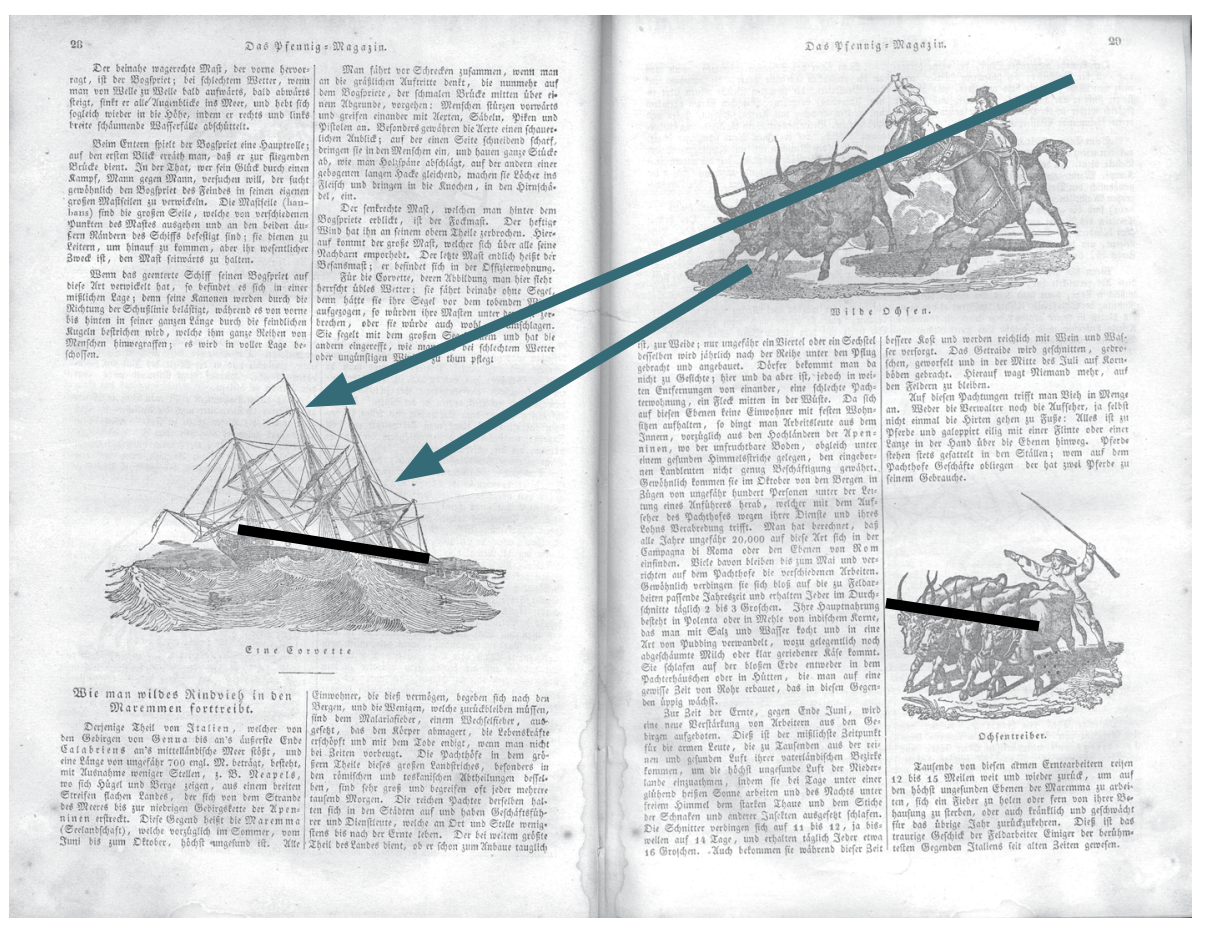

fig. 4a Lines of interaction between the driven cattle and the storm-tossed boat in the Pfennig-Magazin.

Niagara, ${ }^{31}$ whose waters make their way over cliffs while on its banks the white-headed eagle attacks the fish hawk.

This way, the makers of the Magasin Pittoresque, inferior at this time to their British colleagues in terms of manufacturing wood engravings, use stereotype trading to present their magazine as favorable as possible in comparison with the Penny Magazine ${ }^{32}$-they even surpass their British model by designing a rreal magazine double-page spread. The Magasin Pittoresque's illustrated opening shows how to use the new concurrence of images and letterpress on the same page not only to present a single article as self-contained, but to transform the magazine-specific heterogeneity of verbal-visual materials into a meaningful whole. Thus, stereotype trading pushes forward the development of a media specific verbal-visual syntax of the new illustrated

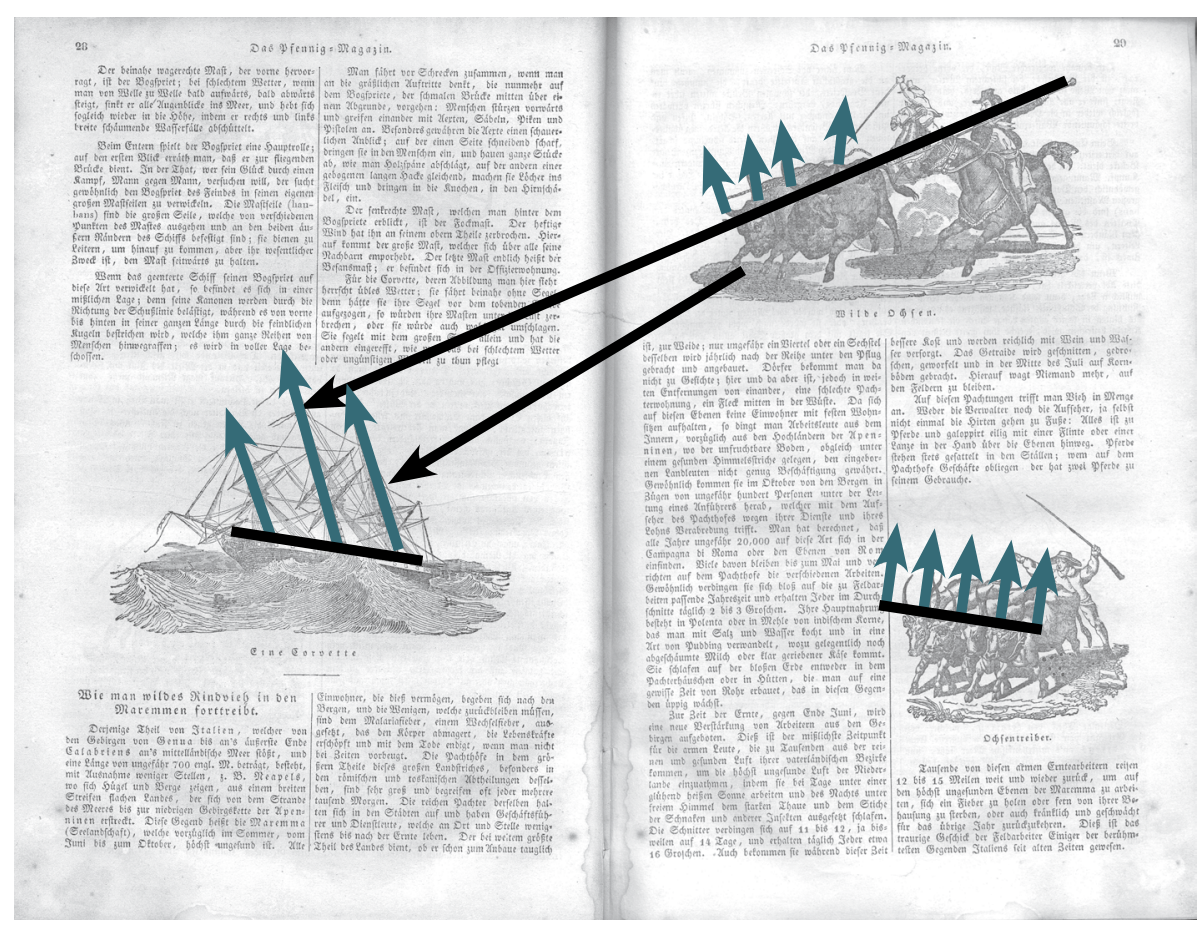

fig. 4b More lines linking the driven cattle and the storm-tossed boat in the Pfennig-Magazin.

magazine, interwoven with economic competition on the young market of illustrated periodicals, and with national sensitivities.

I admit here is good reason to doubt my reading-viewing of the Magasin Pittoresque's double-page spread: the focused opening consists of an issue's last page and of the first page of the following number. How to make plausible that these two pages were designed and viewed-read as a significant whole? First, the Magasin Pittoresque, unlike the Penny Magazine or the Pfennig-Magazin, tries to disguise the interface between its issues and aims at a homogeneous appearance. There is-for the first time in the periodical's run-no masthead with more or less detailed information on the magazine's price and on the conditions of subscription; ${ }^{33}$ just an inconspicuous imprint at the bottom of the verso and the issue's number in the slightly heightened running title of the 
recto page reveal that this opening combines two issues of the magazine. So why not dealing with this opening as one designed surface then? All the more, and secondly, as there were actually reader-viewers who grasped the opening with the two raptors and the Italian cattle as a meaningful whole: the makers of the Leipzig Pfennig-Magazin.

\section{French Layout of British Words and Images}

under German Rule

The Arrival of the Wild Oxen in the Pfennig-Magazin

In 1832/33, French magazine makers might have been behind their British colleagues in terms of manufacturing wood engravings; German magazine makers however were far behind both their British and their French competitors (if you remember the awkward image of Ulm Minster). So why should German reader-viewers, familiar with the Penny Magazine and the Magasin Pittoresque, ${ }^{34}$ take notice of the Pfennig-Magazin? Because they could find there openings like the one shown in fig. $4^{35}$-a stunningly well-calculated rearrangement of stereotypes which surpasses the opening layout of the Magasin Pittoresque which had, for its part, surpassed the opening layout of the Penny Magazine.

At first glance we see that the Italian cattle, reaching Leipzig, is placed à la française on the page, or better: on the opening. The illustrations occupy almost the same position as they did in the Magasin Pittoresque (cf. fig. 3); hence, in the Pfennig-Magazin they also exert pressure from the right, and this leftwards-oriented impulse is taken up by a third illustration which belongs to another article-a feature which also follows the model of the $M a$ gasin Pittoresque. The third engraving, however, doesn't show the raptors' fight, ${ }^{36}$ but a >corvetter sailing sin bad weather, ${ }^{37}$ only the storm jib set, >before the raging wind ${ }^{38}$ by which it is driven to the left. The raging wind's force is made visible by the illustrated opening, as on the opposite page >wild oxen ${ }^{39}$ are driven to the left-towards the ship, to which the two aggression lines of the animals' depiction point, as they did in the Magasin Pittoresque to the ea- gle and the fish hawk (fig. 4a). The yoke points to the corvette; corresponding to the subjugated oxen (and the attacked fish hawk), the ship has been inclined by the heavy gale-its violence is symbolized by the impact direction of the front horseman's lance and the cattle's escape direction: both point, according to this metaphorization, to the corvette's rigging, where all sails are stricken in order to minimize the targets for the wind. Hence, driving the cattle makes the invisible force of the wind, driving the ship, visible on the surface of the periodical's illustrated opening. By suggesting friction between the dynamics of the oxen images and the static letterpress, the violent dynamics of the wood engravings are transmitted to the corvette. It is the interaction of images and typeset text that makes the force of the storm optically perceptible; if the opening were empty apart from the images, their arrangement wouldn't produce this effect.

The Magasin Pittoresque's well-calculated opening is not just copied by the Pfennig-Magazin, but deliberately varied in an analogous way. This shows, almost incontestably I hope, that the Leipzig magazine makers knew to readview the opening layout of the French periodical as a semanticized whole-and it indicates that we may cautiously assume that the international contemporary audience of illustrated magazines generally had this competence. But the German adaptation of the French opening layout shows even more, it shows that the Pfennig-Magazin's makers recognized the French layout solution as a surpassing of the Penny Magazine's mise-en-page.

However, the main source of the German version of the Maremma article is not the Magasin Pittoresque: while the structure of the opening's visual design with its dynamic effects was borrowed from Paris, the stereotypes are of London origin, and the article's verbal part is a partial translation of the Penny Magazine's account. ${ }^{40}$ Hence, the Pfennig-Magazin provides a hybrid by which it handles over the content of the British model to the form of its French counterpart: a hint for reader-viewers to fix their eyes on the French textual architecture as a surpassing of the English layout.

At this stage, we still haven't fully exhausted the compositional refinement of the Pfennig-Magazin's opening. When its version of the Maremma article gives preference to the Magasin Pittoresque over the Penny Magazine, it 
claims, at the same time, its own superiority over the French periodical. The German magazine makers not only exhibit that they knew to appreciate the preparation of the rbœuf sauvage on the French opening but they also reveal that by doing so, they had noticed the compositional strategy of the opening where the wood engraved corvette was originally published-and they did not fully approve of it. To understand this, we have to go back to England and have to examine the opening of the Penny Magazine which is shown in fig. 5. No, there isn't any corvette; instead we find, in rather strange coincidental company of a "Giraffe preparing to lie down, « the »Head of the Giraffe, showing the manner of using its tongue in gathering food, ${ }^{41}$ and the $»$ Papyrus,${ }^{42}$ the $»$ West Front of the Cathedral of Rouen. $\aleph^{43}$ The latter illustration "present $[\mathrm{s}]$ a sufficient notion $\aleph^{44}$ of the cathedral, London asserts; in Paris, however, we find a different view when the Magasin Pittoresque embeds the »door-way of the western front, « ${ }^{45}$ the »[f]rontail de la cathédrale de Rouen, $«{ }^{46}$ imported by means of stereotypes, into a coherently composed ensemble of images. To this end, two wood engravings, one of them the corvette which later reappears in the Pfennig Magazin, were produced to accompany the church door on a double-page spread, and these images - of a $>$ Frenchness $<$ emphatically displayed by signatures of the drawer and of the Paris engraving studio in upper case letters ${ }^{47}$ - have been adjusted to the composition of the church door's depiction (fig. 6). The three distinctive towers that dominate the general view

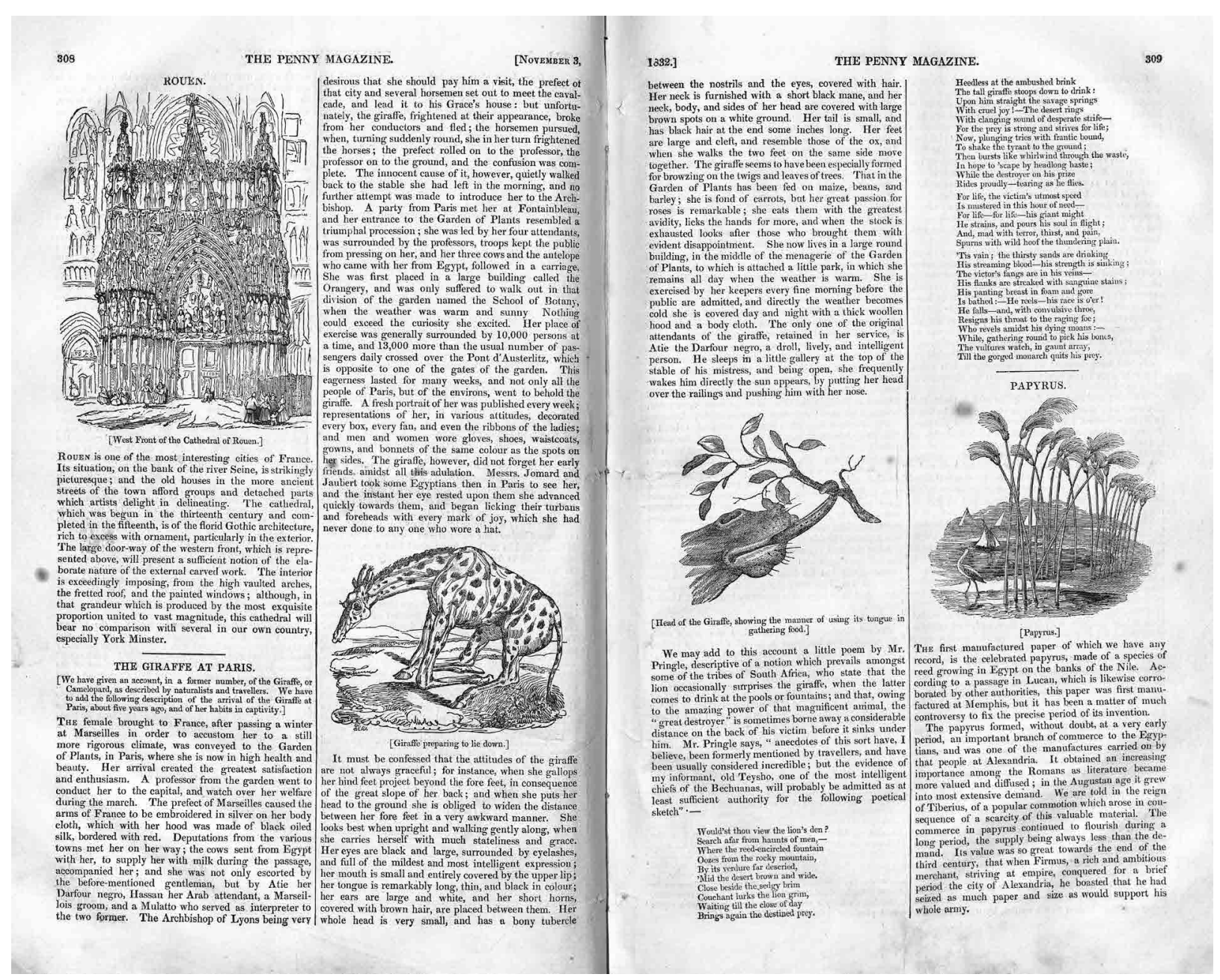

fig. 5 »Rouen.« (left-hand page, wood engraving without signature), »The Giraffe at Paris.« (left- and righthand page, the wood engraving on the left with signature in the lower left corner, the engraving on the right without signature), and »Papyrus. (right-hand page, unsigned wood engraving) Penny Magazine 1, no. 38 (November 3, 1832): 308-9; type area ca. $25.2 \mathrm{~cm} \times 15.3 \mathrm{~cm}$. Early copy, formerly in the library of the English Book Society Hanover (Germany); author's collection. 
of Rouen Cathedral adapt the tripartite vertical orientation of the doorway with its gable flanked by two pinnacles. And in a similar way, the corvette's three masts ${ }^{48}$ which are explicitly mentioned in the text as a characteristic of this type of ship, also show a similarity to the three peaks above the church door (fig. 6a)-another demonstration of power by accomplished French layout in contrast to that of the Penny Magazine.

These analogs of image composition did not escape the makers of the Pfennig-Magazin. As in the case of the wild cattle and the raptors, the assembling of cathedral and corvette is not copied, but varied, namely by deliberately replacing the depictions of Rouen Cathedral by that of the oxen. This might appear strange, but let us look once again at the opening of the Pfennig-Magazin (fig. 4b). Here the oxen show, the article tells us, very large horns, ${ }^{49}$ and, as we can see in the illustrations, the peaks of these horns are ostentatiously protruding upwards; this forms a counterpart to the masts of the corvette, all the more as the horns of the cattle on the image top right, similar to the masts of the ship, are tied by a rope. In this way, the animals' images compensate for the omission of those of the church. Hence, they produce not just a varied imitation, but a surpassing of the Magasin Pittoresque's opening design: the French double-page spread shows a rigid vertical orientation by which the raging dynamics of the ship's depiction are inhibited; the storm-driven corvette is compositionally anchored on an immobile building. This inconsistency is removed in

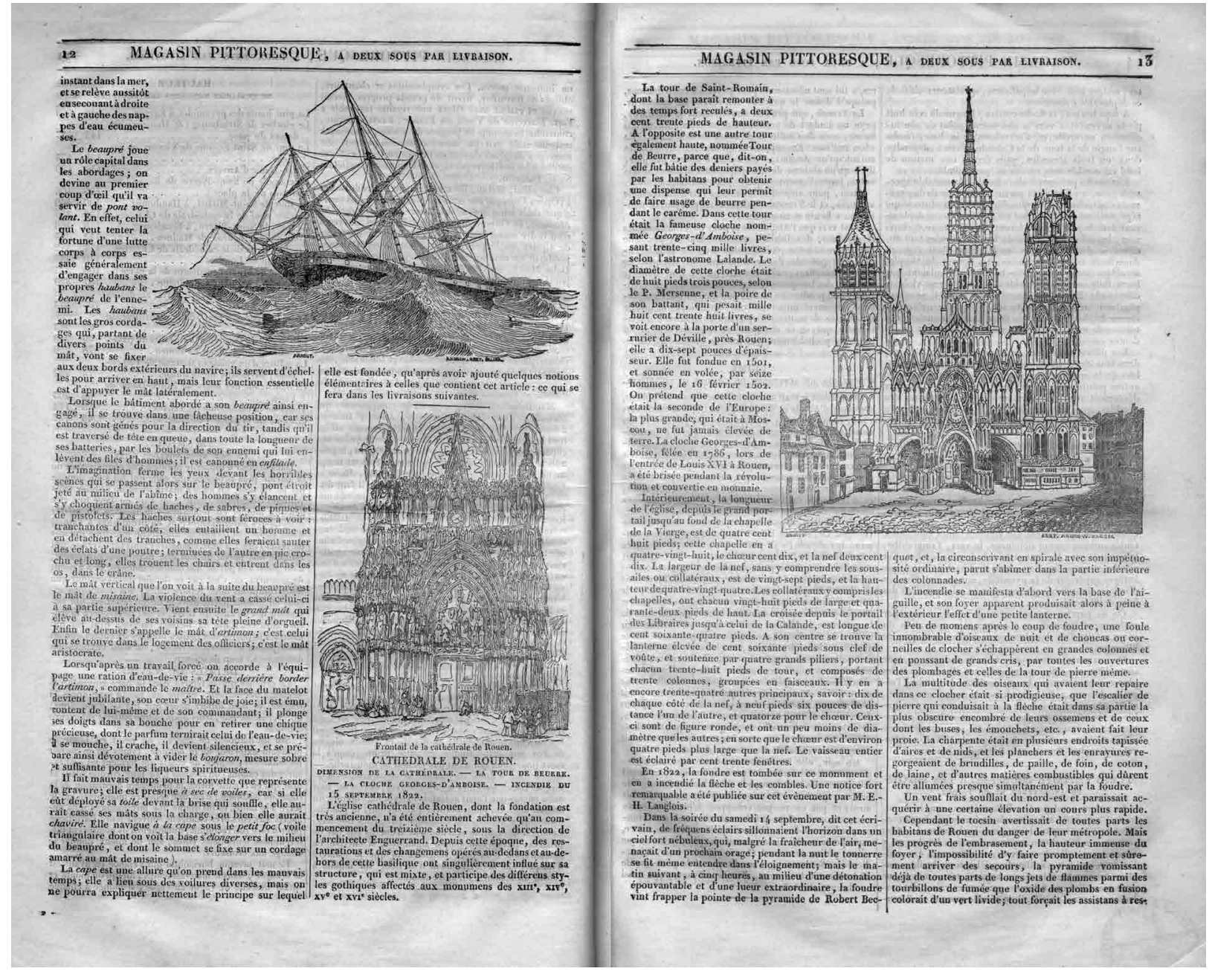

fig. 6 "Marine.« (left-hand page, wood engraving signed at the bottom »ARNOUT» and »ANDREW. BEST. LELOIR.«), »Cathédrale de Rouen." (left- and right-hand page, the wood engraving on the left unsigned, the engraving on the right signed at the bottom »ARNOUT« and »BEST. ANDREW. LELOIR.«) Magasin Pittoresque 1, no. 2 ([February 16, 1833]): 12-13; type area ca. $25.3 \mathrm{~cm} \times 15.3 \mathrm{~cm}$. Early copy, stamped issue (tax stamp ibid., 15); author's collection, no digitized copy available. 
the Pfennig-Magazin by rearranging and varying the foreign image ensemble: driving horned cattle mirrors the drive of the ship, the stereotype in motion sets in motion the French corvette by an impressively complex interaction of wood engravings and letterpress on the German double-page spread.

As the previous elaborations show, it is certainly worth retracing the path of wild Italian cattle across the European media landscape of the 1830s. The oxen's `migration from London to Leipzig via Paris offers the chance to grasp an important process in illustration and thus in media history: the emergence of a new international verbal-visual syntax, in just a few months, in the new media format of the illustrated magazine, driven by migrating stereotypes. This process proves to be not just a phenomenon of aesthetics and/or semiotics, but also a result of economic competition on the magazine market, and, at the same time, a contribution to the formation of national identity in France and Germany. Reused as integral parts of intriguingly complex opening layouts, trans-nationally migrating stereotypes became, to a certain extent, >national stereotypes in Paris and especially in Leipzig. Thus, early illustrated periodicals teach us that nation-building takes place even on the surface of inconspicuous illustrated magazine openings where printing techniques, compositional skills, and economical interests turn out to be instruments of a kind of sethno-graphy<, of a way to render the profile of a nation, of an $\ddot{\varepsilon} \theta v o \varsigma$, readable-viewable by $\gamma \rho \alpha \varphi \eta$, by means of printed writing and wood-engraved drawings. ${ }^{50}$

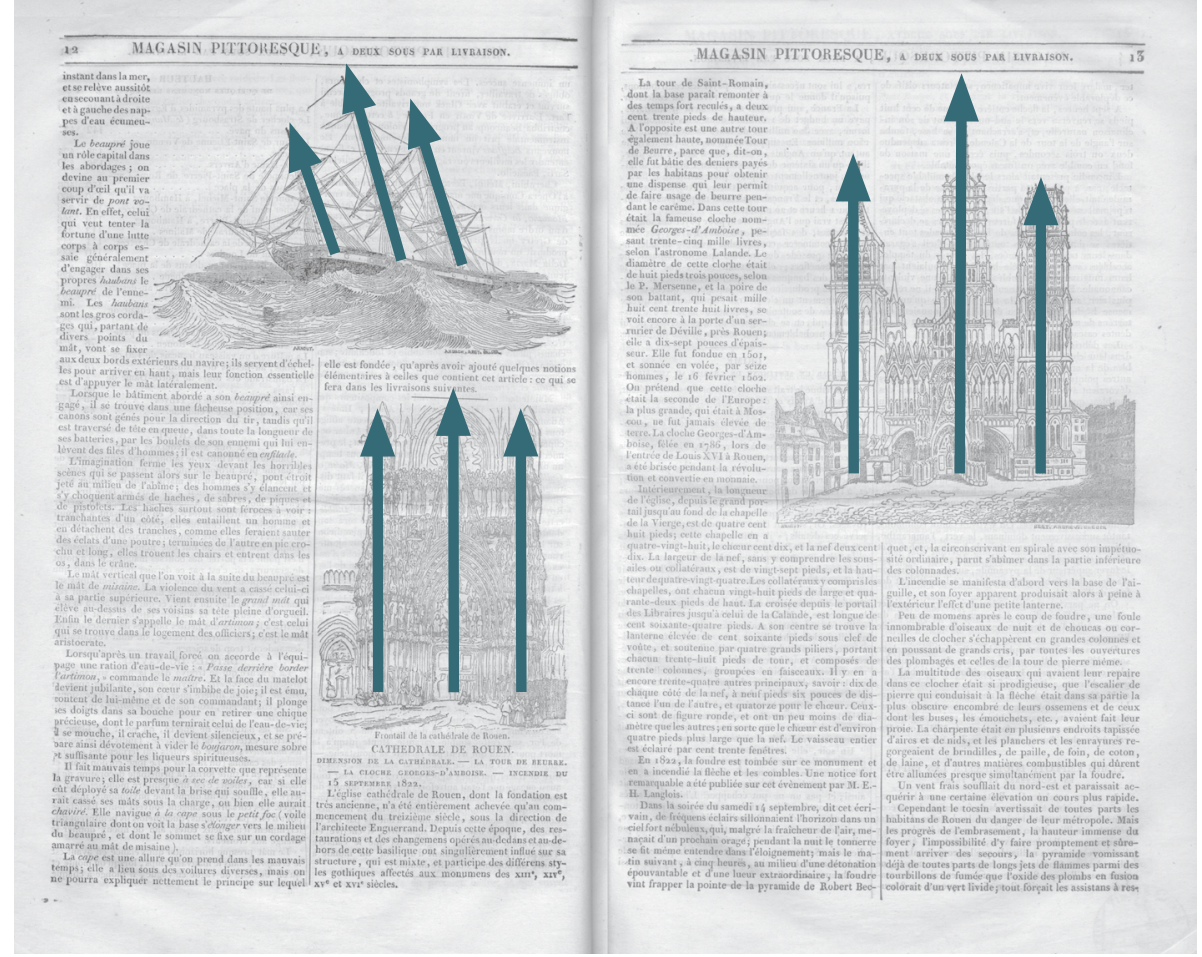

fig. 6a Structural parallels connecting the storm-lashed corvette and Rouen Cathedral in the Magasin Pittoresque. 
1 See »Die Buschmänner, « 214-16. »Le Hottentot, « 411-12. »The Hottentots, "69-71. »Song of the Wild Bushman, 248.

2 See »Neapolitan Maccaroni-Eaters," 304-7. „Die neapolitanischen Maccaroniesser, « 297-99. "Scènes Italiennes: Le Marchand de Macaroni," 401-2.

3 See Gozlan, „Visite des Quatre Académies aux Sauvages Charruas, «33-34. »Die wilden Scharruas, « 73-75.

4 See »Feste und religiöse Gebräuche der Hindus, « 229-30. »Hindoo Festivals, « 244-45.

5 More than ten percent of the Leipzig Pfennig-Magazin's articles are classified as rethnographic by Löffler, »Das Leipziger >Pfennig-Magazin`,« 316. - On `ethnographic^/>ethnological topics in the Magasin Pittoresque see Aurenche, Édouard Charton et l'invention du >Magasin pittoresque،, 233-34, and 240-46.

6 The term sparatext signifies the multifarious means which render a text receivable, i.e. visible, tangible, readable, understandable for readerviewer-handlers, such as inter alia, title, author's name, footnotes, foreword or afterword-but also non-verbal elements as page numbers, binding, paper, typeface, or layout. See Genette, Seuils, $\mathrm{Pa}$ ratexte: Das Buch vom Beiwerk des Buches, and/or Paratexts: Thresholds of Interpretation.

7 The Bochum research unit »Journalliteratur» has recently approached this subject, see Beck, Kaminski, Mergenthaler, and Ruchatz, eds.,
Visuelles Design: Die Journalseite als gestaltete Fläche: Visual Design: The Periodical Page as a Designed Surface.

8 »Illustration."

9 See, for example, Pfeifer, ed. Etymologisches Wörterbuch des Deutschen, 572. Blachon, La gravure sur bois au XIX $X^{e}$ siècle, 9.

10 There are four main preconditions of this phenomenon: the advancement of wood engraving in the late eighteenth and early nineteenth century; the invention of the steam-driven printing press; the development of machines producing large amounts of paper; and the further development of stereotyping, which allowed to print several solid quality copies of a text with wood engravings at the same time on machine-made paper by highspeed printing machines. On this complex topic see Beck, Wie frühe illustrierte Journale (nicht) über sich Auskunft geben, 50-52. Hanebutt-Benz, Studien zum deutschen Holzstich im 19. Jahrhundert, 687-90. Mainardi, Nineteenth-Century Illustrated Print Culture, 73.

11 On the five-figure to six-figure circulation of English, French, and German penny magazines in these years, see Aurenche, Édouard Charton et l'invention du >Magasin pittoresque , 139. Bacot, La Presse illustrée au XIX siècle, 2005: 36-38. Blachon, La gravure sur bois au XIX siècle, 99. Buchanan-Brown, Early Victorian Illustrated Books, 25-27. Bucher, "Zur Multimodalität der Illustrierten Zeitungen und Zeitschriften im 19. Jahrhundert,« 33. Gebhardt, »Die Pfennig-Magazine und ihre Bilder, 23. HanebuttBenz, Studien zum deutschen Holzstich im 19. Jahrhundert, 675, 689-90, 692, 697, and 704-5. Löffler, »Das Leipziger `Pfennig-Magazin`,« 313.

12 See, for example, Frisch, Nouveau Dictionnaire des Passagers François - Allemand et Allemand - François, French-German dictionary 1145. Fröhlich von Fröhlichsburg, Commentarius, In Kayser Carl des Fünfften, und des H. Röm. Reichs Peinliche Halsgerichts-Ordnung, additiones 2. Wheatly, A Rational Illustration of the Book of Common Prayer, title page and 23.

13 The relevance of the quantitative aspect for the coming up of the current meaning of sillustration s should not be underrated; it is rather unlikely that a semantic change of the term had occurred if the production of printed texts with no or only few images remained the general rule.

14 »Commercial History of a Penny Magazine.No. III,« 471.

15 »Commercial History of a Penny Magazine.No. II,« 421.

16 Ibid., 420.

17 See "Strasburg Cathedral,« 313. Jackson's wood engraving was reprinted by the Magasin Pittoresque 2, no. 9 ([March 1, 1834]): 69, and by the Pfennig-Magazin 1, no. 49 (April 5, 1834): 388.The issue used for reproduction (like most numbers in the Penny Magazine's first two volumes of this provenance) had been obviously folded 
before becoming part of a bound volume. This might indicate that the Hanover copies do not provide later reprints by volumes (in which cases issues were not, as far as I see, folded for postal delivery or storage) but probably early, perhaps even the first printed issues sold in $1832 / 33$. This presumption is supported by the fact that no. 32 is missing in the first Hanover volume, without apparent damage to the volume's binding. Furthermore, there are remains of paper wrappers in the gutter (for example vol. 1, 168-69, 208-9, 296-97, and 344-45; vol. 2, 208-9 and 248-49) by which the entire volume is still divided into the monthly parts to which the North German reader-viewers probably subscribed.

18 See »Der Dom zu Ulm, « 305. The illustration is signed »Finckh« in the lower right corner. On this wood engraver (whose first name seems to be unknown), see Hanebutt-Benz, Studien zum deutschen Holzstich im 19. Jahrhundert, 699, 733, and 1038.

19 The light-dark contrast on the Swabian cathedral's forecourt is intended to give depth to the image-but there is not, as in Jackson's engraving, a clear succession of darker foreground and brighter middle ground; instead, we see a rather ineffective bright spot of puzzlingly irregular shape. Similarly, the houses in the lower right corner of the German illustration are also expected to simulate spatial depth but fail to produce this impression, for they do not present their fronts, as the buildings we see to the left of Strasbourg Cathedral do, in a significantly oblique view. Finally, people in front of Ulm Minster, as their counterparts in the Penny Magazine, are meant to give life to the church's depiction-but this personal staffage consists of clumsily coarse stick figures that are anxiously placed on the white sections of the forecourt: The German wood-engraver, obviously being limited in his skills, avoided the difficulties to work out figures against a dark background. Furthermore, the proportions of these figures are incorrect; the rider in front of the church gate appears too small in relation to the pannier-carrying walking figure beneath him.

20 »Commercial History of a Penny Magazine.No. II,« 420-21.

21 Ibid., 420.

22 "Commercial History of a Penny Magazine.No. III, « 471. Italics and blackletter in original.

23 »eine [...] etwas matte Kopie der englischen Journale.« »Unsern geehrten Abonnenten und dem Publikum, « verso of the volume's title page.

24 "gleichsam [...] parodirende Nachahmung[ ] ausländischer Originale.« Ibid.

25 »hr eifrigstes Bestreben dahin richten, dieser Zeitschrift immer mehr einen nationalen Charakter [..] $\mathrm{zu}$ geben." "An die Leser,« 625. Spaced-out words in original.

26 See National-Magazin 1 (1834); ceased publication with this volume.

27 »Labourers of Europe.-No. 2,« 196-97.

28 »The following cut, as well as the head of this article, represents the mode of driving cattle to the towns.« Ibid., 197.
29 See »Bœuf sauvage dans la Maremme,« 33.Collating all copies of the Magasin Pittoresque's first seven livraisons available to me until now, I figured out that over the years, these issues were published in no less than nine (at least slightly differing) versions, at least as far as I can tell. The figures in this paper, reproducing pages of the magazine's stamped issues (>livraisons timbrées`) which were sold weekly in 1833 , show the earliest version.

30 See »White-Headed or Bald Eagle, 245.

31 "cataracte du Niagara." "Lutte de l'aigle à tête blanche et du faucon pêcheur, « 32 .

32 The visual design of the Magasin Pittoresque's very first page adapts the look of the very first page of the Penny Magazine; cf. Magasin Pittoresque 1, no. 1 ([February 9], 1833): 1, and Penny Magazine 1, no. 1 (March 31, 1832): 1. This >branding`shows that the makers of the new periodical expected their reader-viewers to be familiar with the Penny Magazine; see Beck, Wie frühe illustrierte Journale (nicht) über sich Auskunft geben, 14 and 31.

33 See the title pages of the Magasin Pittoresque's first five numbers, of the magazine's stamped issues, which were sold weekly in 1833. From this very first edition, the title pages of the not stamped issues, sold monthly in 1833, differ slightly (at least in my copy). See and cf. Magasin Pittoresque 1 (1833), >livraisons timbrées` and >livraisons non timbréesı, 1, 9, 17, 25, and 33; author's collection, no digitized copies available.

34 The visual design of the Pfennig-Magazin's 
very first page >quotes the appearance of both the Penny Magazine's and the Magasin Pittoresque's very first page; cf. Pfennig-Magazin 1, no. 1 (May 4, 1833): 1, Penny Magazine 1, no. 1 (March 31, 1832): 1, and Magasin Pittoresque 1, no. 1 ([February 9,] 1833): 1. Thus, we may conclude that the makers of the Pfennig-Magazin assumed that their reader-viewers also read-viewed the Penny Magazine and the Magasin Pittoresque; these were sold by the Pfennig-Magazin's editor at Leipzig, see Intelligenz-Blatt zum Pfennig-Magazin, no. 4 (December 21, 1833): [1] and [3-4] —and they were bought in Germany, as my copies of the first volumes of the Penny Magazine show, carrying engraved bookplates of the English Book Society Hanover. See furthermore Beck, Wie frühe illustrierte Journale (nicht) über sich Auskunft geben, 10-15.

35 At least two versions of this issue can be figured out. In the copy reproduced here, the left column's last line on the right-hand page reads »16 Groschen. Auch bekommen sie während dieser Zeit«, whereas in other copies we find »Die Schnitter verdingen sich auf 11 bis 12, ja bis-« (author's collection; copy of the Bayerische Staatsbibliothek, Munich, see https://www.digitale-sammlungen. $\mathrm{de} / \mathrm{de} / \mathrm{view} / \mathrm{bsb10531975}$ ? page $=40,41$, last accessed July 4, 2021). The latter version I found solely-at least until now-in copies of the 1834 fifth edition (author's collection; copy of the Bayerische Staatsbibliothek, Munich), whereas the former not only occurs in a fifth edition's parallel version (copy of the Heinrich Heine-University,
Düsseldorf, see https://digital.ub.uni-duesseldorf.de/ihd/periodical/pageview/9219130, last accessed July 4, 2021; copy of the University of Minnesota, see https://babel.hathitrust.org/cgi/pt ?id=umn.31951d00324578h\&view=1up\&seq=37, last accessed July 4, 2021) but also in the earlier $>1^{\text {st }}$ volume, $1^{\text {st }}$ part ( $» 1^{\text {ter }}$ Band, $1^{\text {ste }}$ Abtheilung «) published in $» 1833$ « (title page of the copy of the Theodor Springmann-Stiftung, Heidelberg, and of the reprint of the Pfennig-Magazin's first volume, ed. Reinhard Kaiser, Nördlingen: Greno, 1985 (see https://babel.hathitrust.org/cgi/pt?id=c oo.31924007352523\&view $=1$ lup\&seq $=53$, last accessed July 4, 2021).

36 The Pfennig-Magazin presents the image >of the fight of the white-headed eagle and the fishhawk, »[d]e[s] Kampf[s] des weißköpfigen Adlers und des Fischaars, " already on the last page of the preceding issue-ostentatiously so, one is tempted to say. See »Der Kampf des weißköpfigen Adlers und des Fischaars, 24.

37 »Corvette [...] bei schlechtem Wetter.» »Eine Corvette, $« 8$

38 "vor dem tobenden Winde.« Ibid.

39 »Wilde Ochsen.« »Wie man wildes Rindvieh in den Maremmen forttreibt, « 29.

40 See, for example, the beginning of the German article: »Derjenige Theil von Italien, welcher von den Gebirgen von Genua bis an's äußerste Ende Calabriens an's mittelländische Meer stößt, und eine Länge von ungefähr 700 engl. M. beträgt, besteht, mit Ausnahme weniger Stellen, z. B. Ne a pels, wo sich Hügel und Berge zeigen, aus einem breiten Streifen flachen Landes, der sich von dem Strande des Meeres bis zur niedrigen Gebirgskette der Apenninen erstreckt. Diese Gegend heißt die Marem ma [...].«»Wie man wildes Rindvieh in den Maremmen forttreibt, « 28; spaced-out words in original. This corresponds precisely to the first sentences of the English article: "Тнат part of Italy which borders the Mediterranean, from the mountains of Genoa to the extremity of Calabria, a length of about seven hundred miles, consists, except a few places, such as Naples, where hills intervene, of a broad stripe of flat country extending from the sea-shore to the lower ridges of the Apennine mountains. This region is called the Maremma." "Labourers of Europe.-No. 2, 196; small caps in original. The translation of "about seven hundred miles« by "ungefähr 700 engl[ische] M[eilen]« forms a kind of reference to the English source. By contrast, the French article starts in a different way; as well as the other verbal elements of the Maremma account in the Magasin Pittoresque, its first chapter has no exact equivalent, neither in the Penny Magazine nor in the Pfennig Magazin: "Dans les ouvrage de géographie, on désigne sous le nom de Maremme cette contrée du grandduché de Toscane qui borde la mer Méditerranée ; mais, en réalité , on doit aussi comprendre sous ce nom la campagne de Rome, car c'est partout la même nature.« »Bœuf sauvage dans la Maremme, « 33; italics in original.

41 »The Giraffe at Paris, « 308-9.

42 »Papyrus, « 309. 
46 »Cathédrale de Rouen,« 12.

47 On the Arnouts' (father and son) drawings for the Magasin Pittoresque, see Aurenche, Édouard Charton et l'invention $d u$ >Magasin pittoresques, 2002: 174, 279-80, and 458; on Andrew, Best, and Leloir as important engravers for the
Magasin Pittoresque, see ibid., 143, 175-76, 180, 283-84, and 285-89.

48 »trois mâts, « »Marine, « 11.

49 »sehr große Hörner, »Wie man wildes Rindvieh in den Maremmen forttreibt, « 29.

50 Wood engraved illustration remained a field of inter-national competition for the next decades, at least in Germany. See, for example, Schasler, Die Schule der Holzschneidekunst; with its repeated evaluative comparisons of English, French, and
German wood engraved illustrations, this study presents a ranking similar to the above outlined proto- or crypto-nationalistically strained relations between the Penny Magazine, the Magasin Pittoresque, and the Pfennig Magazin: According to Schasler, French xylographic art surpasses the rather monotone English wood engravings, and German drawers, engravers and printers, if appropriately supported, could outdo both. 


\section{Bibliography}

»An die Leser.«Pfennig-Magazin 2, no. 79 (November 1, 1834): 625.

Aurenche, Marie-Laure. Édouard Charton et l'invention du >Magasin pittoresque (1833-1870). Paris: Champion, 2002.

Bacot, Jean-Pierre. La Presse illustrée au XIX siècle: Une histoire oubliée. Limoges: Presses Universitaires de Limoges, 2005.

Beck, Andreas. Nicht alles glauben, was geschrieben steht! Wie frühe illustrierte Journale (nicht) über sich Auskunft geben. Hannover: Wehrhahn, 2019.

Beck, Andreas, Nicola Kaminski, Volker Mergenthaler, and Jens Ruchatz, eds. 2019. Visuelles Design: Die Journalseite als gestaltete Fläche: Visual Design: The Periodical Page as a Designed Surface. Hannover: Wehrhahn, 2019.

Blachon, Remi. La gravure sur bois au XIX ${ }^{e}$ siècle: L'âge du bois debout. Paris: Éditions de l'Amateur, 2001.

"Bœuf sauvage dans la Maremme.« Magasin Pittoresque 1, no. 5 ([March 9, 1833]): 33-34.

Buchanan-Brown, John. Early Victorian Illustrated Books: Britain, France and Germany 1820-1860. London and New Castle, DE: British Library and Oak Knoll Press, 2005.

Bucher, Hans-Jürgen. »Mehr als Text mit Bild: Zur Multimodalität der Illustrierten Zeitungen und Zeitschriften im 19. Jahrhundert." In Illustrierte Zeitschriften um 1900: Mediale Eigenlogik, Multimodalität und Metaisierung, edited by Natalia Igl and Julia Menzel, 25-73. Bielefeld: transcript, 2016.

»Die Buschmänner.« Pfennig-Magazin 1, no. 27 (November 2, 1833): 214-16.

»Cathédrale de Rouen.« Magasin Pittoresque 1, no. 2 ([February 16, 1833]): 12-14.

"The Commercial History of a Penny Magazine.-No. II. Wood-Cutting and Type-Founding." Penny Magatine 2, no. 101 (October 26, 1833): 417-24.

»The Commercial History of a Penny Magazine.-No. III. Compositors' Work and Stereotyping.« Penny Magazine 2, no. 107 (November 30, 1833): 465-72.

»Eine Corvette.«Pfennig-Magazin 1, no. 4 (May 25, 1833): 27-28.

»Der Dom zu Ulm.« Pfennig Magazin 1, no. 39 (January 25, 1834): 305-7.

»Feste und religiöse Gebräuche der Hindus.« Pfennig-Magazin 1, no. 29 (November 16, 1833): 229-30.
Frisch Johann Leonhard, ed. Nouveau Dictionnaire des Passagers François - Allemand et Allemand - François, Oder Neues Frantzösisch-Teutsches und Teutsch-Frantzösisches Wörter-Buch [...]: Aufs neue vermehrt und verbessert von Mr. Mauvillon. Leipzig: Gleditsch, 1761.

Frölich von Frölichsburg, Joh[ann] Christ[oph]. Commentarius, In Kayser Carl des Fünfften, und des H. Röm. Reichs Peinliche Halsgerichts-Ordnung [...]: Vorjetzo aber mit dienlichen Additionibus versehen durch Johann Georg Scopp. Frankfurt am Main and Leipzig: Wohler, 1759.

Gebhardt, Hartwig. „Die Pfennig-Magazine und ihre Bilder: Zur Geschichte und Funktion eines illustrierten Mediums in der ersten Hälfte des 19. Jahrhunderts." In Populäre Bildmedien: Vorträge des 2. Symposiums für ethnologische Bildforschung Reinhausen bei Göttingen 1986, edited by Rolf Wilhelm Brednich and Andreas Hartmann, 19-41. Göttingen: Schmerse, 1989.

Genette, Gérard. Seuils. Paris: Éditions du seuil, 1987.

- Paratexte: Das Buch vom Beiwerk des Buches. Translated by Dieter Hornig. Frankfurt am Main: Campus Verlag, 1989.

- Paratexts: Thresholds of Interpretation. Translated by Jane E. Lewin. Cambridge: Cambridge University Press, 1997.

»The Giraffe at Paris." Penny Magazine 1, no. 38 (November 3, 1832): 308-9.

Gozlan, Léon. »Visite des Quatre Académies aux Sauvages Charruas. "Musée des Familles 1, no. 5 (October 31, 1833): 33-34.

Hanebutt-Benz, Eva-Maria. Studien zum deutschen Holzstich im 19. Jahrhundert. Frankfurt am Main: Buchhändler-Vereinigung, 1984.

»Hindoo Festivals.« Saturday Magazine 1, no. 31 (December 29, 1832): 244-45.

»Le Hottentot.« Magasin Pittoresque 1, no. 52 ([December 28, 1833]): 411-12.

»The Hottentots.« Penny Magazine 2, no. 57 (February 23, 1833): 69-71.

»Illustration." In Oxford Advanced Learner's Dictionary, https://www.oxfordlearnersdictionaries.com/definition/english/illustration?q=illustration. Oxford: Oxford University Press, 2021. Last accessed July 4, 2021.

Intelligenz-Blatt zum Pfennig-Magazin, no. 4 (December 21, 1833). 
»Der Kampf des weißköpfigen Adlers und des Fischaars.« Pfennig-Magazin 1, no. 3 (May 18, 1833): 23-24.

»The Labourers of Europe.-No. 2.« Penny Magazine 1, no. 24, (August 18, 1832): 196-97.

Löffler, Katrin. »Das Leipziger 〉Pfennig-Magazin`: Die Anfänge der illustrierten Presse in Deutschland." Leipziger Jahrbuch zur Buchgeschichte 24 (2016): 313-40.

"Lutte de l'aigle à tête blanche et du faucon pêcheur.« Magasin Pittoresque 1, no. 4 ([March 2, 1833]): 32.

Magasin Pittoresque 1, no. 1 ([February 9], 1833).

Magasin Pittoresque 1 (1833), stamped issues (`livraisons timbrées`), printed in 1833 and sold weekly.

Magasin Pittoresque 1 (1833), not stamped issues (>livraisons non timbrées`), printed in 1833 and sold monthly.

Mainardi, Patricia. Another World: Nineteenth-Century Illustrated Print Culture. New Haven and London: Yale University Press, 2017.

»Marine." Magasin Pittoresque 1, no. 2 ([February 16, 1833]): 11-12.

Das National-Magazin für Haus- und Landwirthschaft, National-Unterricht, Statistik und Reisen, neue Erfindungen, National-Unternehmungen und Verbreitung nützlicher Kenntnisse 1 (1834).

»Neapolitan Maccaroni-Eaters.« Penny Magazine 2, no. 87 (August 10, 1833): 304-7. »Die neapolitanischen Maccaroniesser.« Pfennig-Magazin 1, no. 38 (January 18, 1834): 297-99.
»Papyrus." Penny Magazine 1, no. 38 (November 3, 1832): 308-9.

The Penny Magazine of the Diffusion of Useful Knowledge 1, no. 1 (March 31, 1832).

Das Pfennig-Magazin der Gesellschaft zur Verbreitung gemeinnütziger Kenntnisse 1, no. 1 (May 4, 1833).

Pfeifer, Wolfgang, ed. Etymologisches Wörterbuch des Deutschen. Munich: dtv, 1995. »Rouen.« Penny Magazine 1, no. 38 (November 3, 1832): 308.

"Scènes Italiennes: Le marchand de macaroni.« Magasin Pittoresque 1, no. 51 ([December 28, 1833]): 401-2.

Schasler, Max. Die Schule der Holzschneidekunst: Geschichte, Technik und Aesthetik der Holzschneidekunst. Leipzig: Weber, 1866.

»Song of the Wild Bushman.« Penny Magazine 1, no. 30 (September 22, 1832): 248.

»Strasburg Cathedral.« Penny Magazine 2, no. 88 (August 17, 1833): 313-15.

»Unsern geehrten Abonnenten und dem Publikum.«Sonntags-Magazin 1 (1833/34): verso of the volume's title page.

Wheatly, Charles. A Rational Illustration of the Book of Common Prayer. Third edition. London: Bettesworth et al., 1720.

»White-Headed or Bald Eagle.« Penny Magazine 1, no. 30 (September 22, 1832): 245-46. »Wie man wildes Rindvieh in den Maremmen forttreibt."Pfennig-Magazin 1, no. 4 (May 25, 1833): 28-30.

»Die wilden Scharruas.« Sonntags-Magazin 1, no. 10 (January 4, 1834): 73-75. 